УДК 330.3;338.5

DOI: https://doi.org/10.32840/2522-4263/2019-6-11

Робул Ю.В.

кандидат фізико-лателатичних наук, доцент, доцент кафедри ларкетингу та бізнес-адліністрування Одеського національного університет імені I.I. Мечникова

\author{
Candidate of Physical and Mathematical Sciences, Associate Professor, \\ Associate Professor at the Department of Marketing and Business Administration \\ Odessa I.I. Mechnikov National University

\section{МАРКЕТИНГОВА ПОЛІТИКА, ФУНКЦІОНУВАННЯ МАРКЕТИНГОВИХ СИСТЕМ ТА ЗАБЕЗПЕЧЕННЯ СУБ'СКТИВНОГО ДОБРОБУТУ}

Robul Yuriy

\title{
MARKETING POLICY, MARKETING SYSTEMS AND SUBJECTIVE WELL-BEING
}

\begin{abstract}
АНОТАЦІЯ
У статті досліджується зв'язок маркетингової політики на макро- та мікрорівні і суб'єктивного добробуту (subjective wellbeing) - категорії, яка $€$ важливою як для зростання ефективності та результативності інноваційного процесу, так і для забезпечення сталого розвитку економічних систем. У межах соціологічної та поведінкової концепцій маркетингу помічається відхід від парадигми «економічної людини» і включення до критеріїв ухвалення купівельних рішень чинників, пов'язаних із системами цінностей. Як в основі цінностей, так і в основі суб'єктивного добробуту лежать потреби людини. Задоволення чи незадоволення потреб впливає як на формування цінностей, так і на відчуття щастя. 3 іншого боку, колективне прагнення до поліпшення умов життя визначає орієнтацію не тільки на кількісне зростання, а й на зростання якісне. Таким чином, маркетингова політика стає дотичною до зростання якості пропозицій цінності, причому саме у маркетинговому, а не в технічному сенсі, якості споживання, а через неї - якості життя i зростання людського капіталу. У статті проаналізовано модель зв'язку маркетингової політики та суб'єктивного добробуту i зроблено висновки щодо необхідності якісної видозміни маркетингової політики в бік розширення сфери відповідальності маркетингу відповідно до парадигми маркетингу відносин.

Ключові слова: маркетинг, маркетингова система, суб'єктивний добробут, економіка щастя, соціоекономічна система, цінності.
\end{abstract}

\section{АННОТАЦИЯ}

В статье исследуется связь маркетинговой политики на макро- и микроуровне и субъективного благополучия (subjective well-being) - категории, которая является важной как для роста эфффективности и результативности инновационного процесса, так и для обеспечения устойчивого развития экономических систем. В рамках социологической и поведенческой концепций маркетинга замечается отход от парадигмы «экономического человека» и включение критериям принятия покупательских решений фракторов, связанных с системами ценностей. Как в основе ценностей, так и в основе субъективного благополучия лежат потребности человека. Удовлетворение или неудовлетворение потребностей влияет как на формирование ценностей, так и на ощущение счастья. С другой стороны, коллективное стремление к улучшению условий жизни определяет ориентацию не только на количественный рост, но также и на рост качественный. Таким образом, маркетинговая политика начинает иметь отношение к росту качества предложений ценности, причем именно в маркетинговом, а не в техническом смысле, качества потребления, а через нее качества жизни и увеличение человеческого капитала. В статье проанализирована модель связи маркетинговой политики и субъективного благополучия и сделаны выводы о необходимости качественного видоизменения маркетинговой политики в сторону расширения сферы ответственности маркетинга в соответствии с парадигмой маркетинга отношений.

Ключевые слова: маркетинг, маркетинговая система, субъективное благополучие, экономика счастья, социоэкономическая система, ценности.

\section{ANNOTATION}

The article addresses the relationship of marketing policies at the macro and micro levels and subjective well-being - a category that is important both for increasing the efficiency and effectiveness of the innovation process, and for ensuring the sustainable development of economic systems. In the framework of sociological and behavioral concepts of marketing, a departure from the paradigm of the "economic person" is observed and inclusion of factors related to value systems in the criteria for making purchasing decisions takes place. Marketing and subjective well-being are supposed to be related due to the common basis of human needs, which are the foundation for values as well as for subjective well-being. Satisfying or dissatisfying needs affects both the formation of values and the feeling of happiness. On the other hand, the collective desire to improve living conditions determines the orientation not only on quantitative development of marketing system, but also on qualitative growth. Thus, the marketing policy becomes tangent to the growth of the quality of value propositions, bearing marketing sense, going much further technical compliance, meaning a necessity for a considerable leap in customer experience and, therefore in collective customer experience, and essentially in the quality of consumption. However, the relations of marketing and subjective well-being are neither simple, nor linear. They are supposed to have many faceted links at different level of socio-economic system and can be traced among other through the notion of human capital. The quality of consumption, determines growth in quality of life and the growth of human capital. The article analyzes the model of the relationship of marketing policy and subjective well-being, which combines marketing strategies, empirical experience, objective to maximize utility, this time including tangible and intangible assets and criteria, and draws conclusions about a place for marketing in promoting well-being through responsible consumption and education, and a need for a dramatic shift in marketing policy in the direction of expanding of its scope in accordance with the relationship marketing paradigm.

Key words: marketing, marketing system, subjective well-being, economy of happiness, socio-economic system, values.

Постановка проблеми у загальному вигляді та її зв'язок із важливими науковими чи практичними завданнями. Дослідження економіки щастя є одним із цікавих напрямів економічних досліджень, інтерес до яких пожвавився в останні десятиліття, що призвело, зокрема, до 
появи терміна «економіка щастя». Прагнення добробуту і щастя є важливим чинником, що визначає поведінку людини, у тому числі й економічну, пов'язану з розвитком особистих креативних здібностей, виробництвом інновацій, результативністю та ефективністю праці [1-3].

Економіка щастя оцінює суб'єктивний, індивідуальний добробут через комбінацію економічних та психологічних категорій, широко спираючись на поняття корисності. Дослідження 3 економіки щастя переважно зосереджені на вивченні чинників, відмінних від доходу, що впливають на добробут [4]. Вони добре підходять для визначення тих складників, де існує або може існувати чітка кореляція добробуту з кількісними індикаторами, такими як рівень інфляції, безробіття та нерівність. Проте фокусування лише на доході ризикує пропустити важливі елементи добробуту через те, наприклад, що різні люди по-різному визначають баланс переваг, створюваних матеріальними та нематеріальними цінностям. Наприклад, вони можуть вибрати менш оплачувану, але більш цікаву для себе роботу, або менш зручний, але більш екологічний продукт, тим не менше прагнучи до максимізації корисності у класичному сенсі Вальраса. Дослідження економіки щастя та визначення суб'єктивного добробуту є також важливими для забезпечення сталого розвитку, яке грунтується, серед іншого, на свідомому та відповідальному споживанні, яке неможливе без самостійно визначеної цільової поведінкової установки на суб'єктивний добробут і щастя.

Аналіз останніх досліджень і публікацій, в яких започатковано розв'язання даної проблеми і на які спирається автор. Суб'єктивне відчуття добробуту формується під впливом наявності можливості до споживання, якості пропозиції цінності, наявності вибору та постійної доступності бажаного [5]. Цілком імовірно також, що це відчуття знаходиться під впливом обсягу, якості та змісту інформації, яка циркулює у соціоекономічній системі, яка значною мірою формується під впливом маркетингових комунікацій [6; 7]. Слід відзначити, що класичний маркетинг, реалізовуваний через комплекс 4P маркетинг-менеджменту не дає змоги належною мірою врахувати нематеріальний компонент корисності, пов'язуваний iз відчуттям суб'єктивного добробуту та щастя, зокрема через обмеженість пропонованих інструментів донесення цінності та недостатню увагу до процесу взаємодії зі споживачами та більш широкою аудиторією [8-11].

Таки чином, у зв'язку з дослідженнями суб'єктивного добробуту в межах економіки щастя відкривається ціле поле дослідницьких питань, які досі не знайшли свого вирішення, зокрема визначення механізму та ступеню впливу маркетингової політики на суб'єктивне благополуччя особи і переформатування маркетингової політики для кращого прилаштування до потреби створення й зміцнення відчуття суб’єктивного добробуту і щастя. На сучасному етапі розвитку цивілізації відчуття добробуту, щастя та задоволення життям зазнає змін. Соціологи та психологи наголошують на тому, що важливу роль у цьому відіграють соціокультурні процеси, що відбуваються в усьому світі й у кожній країні зокрема. Це знайшло своє відображення у соціологічній та психологічній теоріях маркетингу, наприклад [12-14]. Збільшення кількості населення, високий рівень урбанізації, загострення екологічних проблем, глобальні процеси, безумовно, здійснюють чималий вплив на задоволення життям [15; 16$]$.

Формулювання цілей статті (постановка завдання). Мета статті полягає у тому, щоб визначити основні маркетингові інструменти, які мають вплив на суб'єктивне благополуччя особи, й те, у який спосіб маркетингова політика здійснює вплив на добробут через розвиток соціоекономічної системи у цілому.

Виклад основного матеріалу дослідження 3 повним обгрунтуванням отриманих наукових результатів. Більшість сучасних теорій цінностей так чи інакше вказуе на зв'язок цінностей та відчуття щастя і задоволеності життям. Можна виділити декілька ключових ідей, які пов'язують ціннісні пріоритети та суб'єктивне благополуччя.

Як в основі цінностей, так i в основі суб'єктивного добробуту лежать потреби людини. Задоволення чи незадоволення потреб впливає як на формування цінностей, так і на відчуття щастя.

У нинішніх умовах велике значення мають принципи управління суспільством, які забезпечують пошук шляхів якісного поліпшення життєвих умов людини. Таким чином, прагнення до поліпшення умов життя спонукає суспільство орієнтуватися не стільки на кількісне економічне зростання, скільки на зростання якісне. Головною рисою економіки під впливом глобалізації стане конкуренція між країнами за якість життя, яка забезпечує формування та розвиток людського капіталу та визначає позиції країни на міжнародній арені.

За структурними складниками людського капіталу можна характеризувати i окремого індивіда, і соціальну групу, і соціоекономічну систему в цілому. Показники, які стосуються матеріального та духовного боків розвитку індивіда або суспільства, утворюють непорушну єдність. Досвід засвідчує, що було б невірно на шкоду одній недооцінювати або переоцінювати значення іншої, що має дуже велике значення для визначення місця держави у світовому просторі, ïi ролі у розподілі праці та конкурентоспроможності.

Суб'єктивний добробут споживачів не є тотожним задоволенню споживчих потреб, хоча ці два поняття схожі та близькі. Суб'єктивний добробут відображає загальне відчуття задоволення в житті, тоді як споживче задоволення стосується тільки споживання. Задоволеність 
споживачів оцінюе фактичні результати порівняно з очікуваннями, які, як правило, орієнтовані на певну частину досвіду протягом кількох проміжків часу. Розчарування - це також порівняння, але воно протиставляє вибраний варіант із минулими варіантами. Споживче щастя - це резюме змінних, де важливим є досвід у сфері споживання і де, таким чином, інтегрується задоволеність та розчарування у зв'язку з позитивним і негативним афективним досвідом.

Модель зв'язку маркетингової політики та суб'єктивного добробуту повинна містити, з одного боку, маркетингові стратегії, які під впливом емпіричного досвіду та прагнення максимізувати корисність призводять до збільшення або зменшення суб'єктивного добробуту. Схематично таку модель наведено на рис. 1.

Взаємовідносини 1 та 2 є основними відносинами, які стосуються створення відчуття суб'єктивного добробуту. Маркетингові стратегії визначають те, як створюються пропозиції цінності й як відбувається оцінка споживачами їхніх купівельних можливостей.

Наприклад, стратегії розподілу впливають на безпосередню доступність товарів і створення нових каналів, таких як Інтернет- торгівля, що підвищує зручність, доступність і загалом поліпшує досвід покупки. Маркетингові стратегії будуть впливати на суб'єктивний добробут тих, хто бачить споживчий досвід важливою частиною життя.

Зв'язок 3 відбиває придбання товарів та послуг під впливом емпіричного досвіду. Цей досвід формується попереднім досвідом індивіда, інформацією про досвід, одержаний іншими людьми 3 кола (мережі) спілкування даного індивіда, а також, що важливо у нашому контексті, під впливом колективного знання, яке набуває форму чуток. Це придбання товарів та послуг знаходиться під сильним впливом домінуючих соціальних цінностей, таких, наприклад, як у моделі культурних цінностей Хофстеде [18]. Стереотипні очікування корисності залежать від специфічної взаємодії культурних цінностей та сукупності маркетингових зусиль, яким споживачі та широка публіка надали свою оцінку. Цей зв'язок віддзеркалює також узвичаєні паттерни поведінки, оцінки та ухвалення рішень як щодо покупок, так і щодо створення пропозиції цінності. Зв'язок 4 показуе споживання, здійснюване під впливом прагнення отримати максимальну корисність і відбиває прагнення «економічної людини». Зв'язок 7 показує товари, які купляються не на основі емпіричного досвіду, а у сподіванні отримати такий позитивний емпіричний досвід. Наприклад, придбання подорожей може мати помітний безпосередній вплив на суб'єктивне відчуття добробуту ще до того, як споживчий досвід, власне, склався, оскільки сам факт придбання такого товару визнається ознакою добробуту.

Зв'язок 4 також показує, що тенденції максимізації можуть мати вплив на відчуття добробуту, причому цей вплив не є однозначним. 3 одного боку, високий рівень споживання може сприйматися як ознака добробуту, проте люди, що прагнуть максимуму, можуть бути менш задоволені своїм покупками. Зв'язок 6 відбиває очікування людей по відношенню до покупок i спрямовують їх до стратегії максимізації, коли їх очікування посилюються. Наявність зв'язку 6 може бути емпірично підтверджена роздрібною онлайн-торгівлею (зниження витрат на пошуки призводять до максимізації) чи надання вибору або за допомогою інших засобів, які знижують витрати на пошуки та впливу очікування [17].

Маркетингова діяльність може мати істотний вплив на суб'єктивний добробут. Наприклад, інвестиції в поліпшення мереж дистрибуції створюють значний потенціал для створення корисності місця і часу й, отже, можуть створити додану цінність та підвищити якість життя. Високий рівень життя не може бути забезпечений без розвитку маркетингових обмінів i, відповідно, без системи розподілу $[19 ; 20]$. Реклама може мати позитивний ефект за рахунок збільшення інформації на ринку, також може спостерігатися і негативний ефект через дратівли-

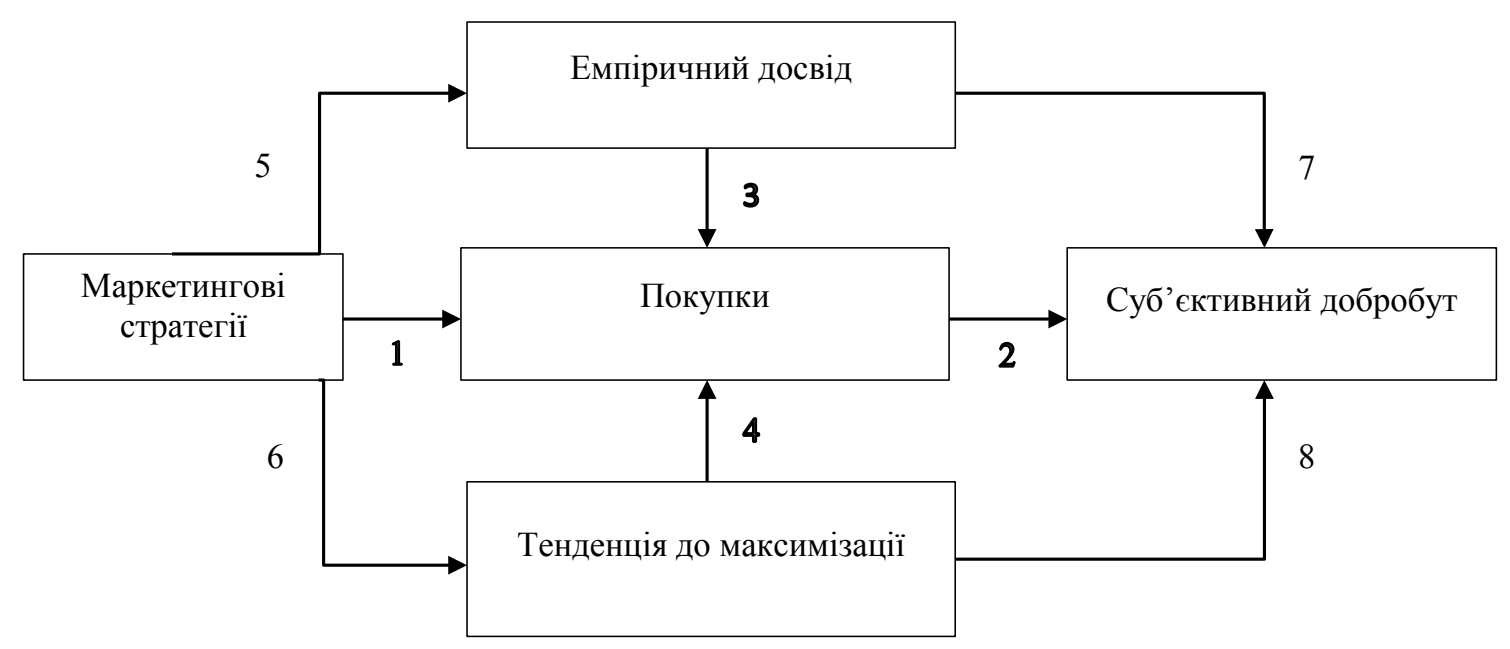

Рис. 1. Модель зв’язку маркетингової політики та суб'єктивного добробуту [17] 
вий або повторюваний характер реклами. Окрім того, якщо в організаціях використовують недоброчесну практику для стимулювання попиту, то маркетингові комунікації можуть посилити певні негативні стереотипи і створити дисфункціональні культурні цінності, маркетингові комунікації можуть вступати в конфлікт із досягненням очікуваного високого рівня добробуту.

Багатовимірний аналіз зв'язку маркетингу та суб'єктивного добробуту показує відсутність щільного зв'язку між маркетинговою політикою та добробутом [5]. Активне застосування маркетингової політики значною кількістю акторів ринку не призводить, звичайно, до автоматичного підвищення суб'єктивного відчуття добробуту на національному рівні через декілька причин. По-перше, ефект маркетингової діяльності сприймається набагато менш очевидним порівняно з іншими, наприклад вплив здоров'я чи безпеки довкілля на якість життя. По-друге, існують значні групи споживачів, яким не подобається розвиток бізнесу в цілому; ці споживачі набагато частіше зауважують на негативні соціальні наслідки чи недоброчесність, які асоціюються з маркетингової діяльністю. Таке ставлення може нівелювати позитивні результати, що маркетингова практика доводить до суспільства.

Підвищення значимості маркетингової політики для зростання суб'єктивного добробуту потребує переоцінки маркетингової політики та розширення сфери їі відповідальності.

Роль маркетингу у розвитку соціоекономічних систем можна розглядати як роль агента соціальних змін. Таким чином, суб'єктивний добробут може бути підвищений за рахунок збільшення взаємозалежності та координації маркетингу 3 іншими соціальними інституціями. Наприклад, маркетинг може відігравати ключову роль у розробленні, просуванні та доставці маркетингових програм для досягнення високих стандартів добробуту. У цьому разі маркетингова політика буде підтримувати підприємницьку діяльність, яка підвищить якість життя.

Висновки 3 цього дослідження і перспективи подальших розвідок у даному напрямку. На підставі проведеного аналізу можна зробити такі висновки.

Вплив маркетингової політики на суб'єктивний добробут є складним i здійснюється на двох рівнях: на рівні взаємодії окремої організації з їі публікою і через створення стереотипних паттернів маркетингової політики, які продукують, своєю чергою, стереотипні моделі поведінки й ставлення споживачів. Використання у великій кількості одних і тих самих маркетингових інструментів, наприклад розширення мереж дистрибуції, або активне використання онлайн-торгівлі сприяє розвиткові всієї соціоекономічної системи через розширення інфраструктури та набуття споживачами корисних звичок, які дають змогу поліпшити ефективність функціонування усієї маркетингової системи.
Позитивний досвід споживання, який прищеплює маркетингова політика, може бути нівельований через негативне ставлення до зловживання окремими маркетинговими інструментами, наприклад із маркетингових комунікацій чи ціноутворення, орієнтованого на психологію. Через це внесок маркетингу у розвиток соціоекономічної системи і підвищення добробуту споживачів вимагає переосмислення його призначення, розширення сфери відповідальності, як, наприклад, це пропонується у холістичній концепції маркетингу та обережного, а разом із тим і всебічного використання інструментів взаємодії, як це передбачається у маркетингу взаємовідносин.

\section{БІБЛІОГРАФІЧНИЙ СПИСОК:}

1. Frey B.S., Stutzer A. Happiness, economy and institutions. The Economic Journal. 1999. № 110(466). P. 918-938.

2. Frey B.S., Stutzer A. Maximising happiness? German Economic Review. 2000. № 1(2). P. 145-167.

3. Kotler P., Zaltman G. Social marketing: an approach to planned social change. Journal of Marketing. 1971. № 35(7). P. 3-12.

4. Aronczyk M. Confidence game: Marketing well-being in economical surveys. European Journal Of Cultural Studies. 2014. № 17(3). P. 244-257.

5. Pan Y., Zinkhan G.M., Sheng S. The Subjective Well-Being of Nations: A Role for Marketing. Journal of Macromarketing. 2007. № 27(4). P. 360-369.

6. Ambler T., Roberts J. Beware the silver metric: marketing performance measurement has to be multidimensional. London : London Business School, 2005. P. 113.

7. Mota G.L. and Pereira P.T. Happiness, Economic Wellbeing, Social Capital and the Quality of Institutions. Technical University of Lisbon Working Papers. 2008. P. 1-27.

8. Barile S., Polese F. Service Dominant Logic and Service Science: a contribute deriving from network theories. The 2009 Naples Forum on Service: Service-Dominant Logic, Service Science, and Network Theory. 2009. P. 1-18.

9. Gummesson E. Extending the service-dominant logic: from customer centricity to balanced centricity. Journal of the Academy of Marketing Science, 2007. № 36(1). P. 15-17.

10. Gummesson E. Exit services marketing-enter service marketing. Journal of Customer Behaviour. 2007. № 6(2). P. 113-141.

11. Gummesson E., Lusch R.F.,Vargo S.L. Transitioning from service management to service-dominant logic: Observations and recommendations. International Journal of Quality and Service Sciences. 2010. № 2(1). P. 8-22.

12. Rossiter J.R., Foxhall G.R. Hull-Spence Behavior Theory as a paradigm for consumer behavior. Marketing Theory. 2008. № 8(2). P. 123.

13. Baker M.J. Marketing: Theory and practice. 1995: Macmillan International Higher Education. $447 \mathrm{p}$.

14. Baker W.E., Sinkula J.M. Market Orientation and the New Product Paradox. Journal of Product Innovation Management. 2005. № 22(6). P. 483-502.

15. Dolan P. The Sustainability of «Sustainable Consumption». Journal of Macromarketing. 2002. № 22(2). P. 170.

16. Frame B., Newton B. Promoting Sustainability Through Social Marketing: Examples From New Zealand. International Journal of Consumer Studies. 2007. № 31(6). P. 571-581. 
17. Ahuvia, A.C., Friedman, D.C. Income, consumption, and subjective well-being: Toward a composite macromarketing model. Journal of macromarketing, 1998. 18(2). p. 153-168.

18. Hofstede G.H., Hofstede G.J., Minkov M. Cultures and Organizations: Software of the Mind. Third edition ed. 2010: McGraw-Hill Professional. 576 p.

19. Layton R.A. On Economic Growth, Marketing Systems, and the Quality of Life. Journal of Macromarketing. 2009. № 29(4). P. 349-362.

20. Layton R.A. Marketing Systems - A Core Macromarketing Concept. Journal of Macromarketing. 2007. № 27(3). P. 227-242.

\section{REFERENCES:}

1. Frey, B.S. and A. Stutzer, Happiness, economy and institutions. The Economic Journal, 1999. 110(466): p. 918-938.

2. Frey, B.S. and A. Stutzer, Maximising happiness? German Economic Review, 2000. 1(2): p. 145-167.

3. Kotler, P. and G. Zaltman, Social marketing: an approach to planned social change. Journal of Marketing, 1971. 35(7): p. 3-12.

4. Aronczyk, M., Confidence game: Marketing well-being in economical surveys. European Journal Of Cultural Studies, 2014. 17(3): p. 244-257.

5. Pan, Y., G.M. Zinkhan, and S. Sheng, The Subjective Well-Being of Nations: A Role for Marketing Journal of Macromarketing, 2007. 27(4): p. 360-369.

6. Ambler, T. and J. Roberts, Beware the silver metric: marketing performance measurement has to be multidimensional. 2005, London Business School. London, p. 113.

7. Mota, G.L. and P.T. Pereira. Happiness, Economic Well-being, Social Capital and the Quality of Institutions. Technical University of Lisbon Working Papers, 2008: p. 1-27.

8. Barile, S. and F. Polese, Service Dominant Logic and Service Science: a contribute deriving from network theories, in
The 2009 Naples Forum on Service: Service-Dominant Logic, Service Science, and Network Theory. 2009. p. 1-18.

9. Gummesson, E., Extending the service-dominant logic: from customer centricity to balanced centricity. Journal of the Academy of Marketing Science, 2007. 36(1): p. 15-17.

10. Gummesson, E., Exit services marketing-enter service marketing. Journal of Customer Behaviour, 2007. 6(2): p. 113-141.

11. Gummesson, E., R.F. Lusch, and S.L. Vargo, Transitioning from service management to service-dominant logic: Observations and recommendations. International Journal of Quality and Service Sciences, 2010. 2(1): p. 8-22.

12. Rossiter, J.R. and G.R. Foxhall, Hull-Spence Behavior Theory as a paradigm for consumer behavior. Marketing Theory, 2008. 8(2): p. 123.

13. Baker, M.J., Marketing: Theory and practice. 1995: Macmillan International Higher Education. 447.

14. Baker, W.E. and J.M. Sinkula, Market Orientation and the New Product Paradox. Journal of Product Innovation Management, 2005. 22(6): p. 483-502.

15. Dolan, P., The Sustainability of\&quot; Sustainable Consumption\&quot; . Journal of Macromarketing, 2002. 22(2): p. 170.

16. Frame, B. and B. Newton, Promoting Sustainability Through Social Marketing: Examples From New Zealand. International Journal of Consumer Studies, 2007. 31(6): p. 571-581.

17. Ahuvia, A.C. and D.C. Friedman, Income, consumption, and subjective well-being: Toward a composite macromarketing model. Journal of macromarketing, 1998. 18(2): p. 153-168.

18. Hofstede, G.H., G.J. Hofstede, and M. Minkov, Cultures and Organizations: Software of the Mind. Third edition ed. 2010: McGraw-Hill Professional. 1-576.

19. Layton, R.A., On Economic Growth, Marketing Systems, and the Quality of Life. Journal of Macromarketing, 2009. 29(4): p. 349-362.

20. Layton, R.A., Marketing Systems - A Core Macromarketing Concepr. Journal of Macromarketing, 2007. 27(3): p. 227-242. 